\title{
Hematological, Biochemical and Histological alterations induced by oral administration of Thiamethoxam and Acetamiprid in male rats
}

\author{
A. A. Hataba ${ }^{1}$, A. T. Keshta ${ }^{1}$, HalaM.I. Mead ${ }^{2}$, NouranM.El-Shafey ${ }^{2}$. \\ 1 Assistant Professor of organic chemistry, Chemistry department, Faculty of Science, Zagazig University, Egypt. \\ 1 Lecture of biochemistry, Chemistry department, Faculty of Science, Zagazig University, Egypt. \\ 2 Senior researcher, Plant Protection Research Institute, Agricultural Research Center \\ 2 Chemist, Plant Protection Research Institute, Agricultural Research Center
}

\begin{tabular}{l}
\hline A R T I C L E I N F O \\
Keywords: \\
Thiamethoxam Acetamiprid, \\
hepatotoxicity, nephrotoxicity,
\end{tabular}

hematological changes

\begin{abstract}
A B S T R A C T
Background: Neonicotinoids have become the most widely used class of insecticides with a global market share of more than $25 \%$. They are a class of neuroactive insecticides chemically related to nicotine. Thiamethoxam is a second generation neonicotinoid insecticide in the thianicotinyl subclass used worldwide that contains nitro group. Acetamiprid is a systemic insecticide, belonging to the chloronicotine subclass and having a broad insecticidal spectrum that contains cyano group. Aim: The present study aims to investigate: Toxic effects of some neonicotinoid insecticides (Thiamethoxam and Acetamiprid) and investigate also biochemical, hematological and histological alterations of these insecticides. Materials \& Methods: Adult male Swiss albino rats were divided into 3 groups: 1st negative control group; 2nd Thiamethoxam group administrated $156 \mathrm{mg} / \mathrm{Kg}$ body weight every day along 30 days; 3rd Acetamiprid group administrated orally $100 \mathrm{mg} / \mathrm{Kg}$ body weight every day along 30 days. Blood, liver and kidney tissues samples were collected for some biochemical, hematological and histopathological studies. At the end of the experiment, animals were scarified every 10, 20 and 30 days. Results: Thiamethoxam and Acetamiprid induced alterations in liver function tests, kidney function tests and hematological parameters. As these changes were accompanied with hepatic necrosis as well as inflammation. Moreover, they induced cloudy swelling of renal tubules and renal inflammation. Conclusion: Our data suggested that, Thiamethoxam may be more hepatotoxic, nephrotoxic and produced hematological changes than Acetamiprid. Use of these insecticides should be limited.
\end{abstract}

(C) 2014 Publisher All rights reserved.

\section{INTRODUCTION}

Neonicotinoids are the fastest growing class of insecticidesdue to their putative moderate toxicity to mammals and their advantage in combating insects that are resistant to other pesticide classes ${ }^{(1)}$. They target the insect nicotinic acetylcholine receptor (nAChR) and are highly effective against the piercing-sucking pests ${ }^{(2)}$. The presence of a strong electron-withdrawing pharmacophoric group, such as cyano or nitro group, is an essential structural characteristic of these insecticides and postulated to contribute directly to their selectivity ${ }^{(3)}$. Thiamethoxam (THIA) is a systemic and contact insecticide. Its chemical name is: $\{3[$ (2-chloro-5-tetrahydro-5thiazolyl)methyl]methyl-N-nitro-4H-1,3,5oxadiazin4-imine $\}^{(4)}$.THIA is used for the controlling a variety of pests such as aphids, whiteflies, thrips, vegetables, cotton and fruits pests ${ }^{(5)}$. THIA metabolism has shown that its 'magic nitro' is transformed to produce nitrosoguanidine, aminoguanidine, guanidine and urea derivatives in mice ${ }^{(6)}$. The metabolites of THIA induce 
hepatotoxicity. As, they inhibit nitric oxide synthase exacerbated the toxicity. This mode of action depend onsingle cell necrosis and an increase in cell replication rates. Accompanying changes included hypertrophy, inflammatory cell infiltration and fatty change in liver mice ${ }^{(7)}$. Acetamiprid (AC) is a member of the neonicotinoid group of insecticide that is highly effective for the controlling aphids, beetles, moth, leafhopper, pests on crops and leafy vegetables ${ }^{(8)}$. $\mathrm{AC}$ is ((E)-N1-[(6-chloro-3-pyridyl) methyl]-N2cyano-N1methylacetamidine). Themain metabolic pathway in animals is the demethylationto IM-2-1 (N1-[(6-chloro-3-pyridyl) methyl]-N2cyanoacetamidine). This metabolite is further transformed to 6-chloronicotinic acid with the release of $\mathrm{N}$-cyanoacetamidinederivative after cleavage from the side-chains ${ }^{(9)}$. All the metabolites were lesser toxicity than the parent (acetamiprid).The predominant metabolite in all tissues is the (IM-2-1 metabolite) desmethylacetamipid, with highest residues in liver and kidney ${ }^{(10)}$.Neonicotinoids affect mainly on brain and cause brain toxicity ${ }^{(11)}$ that affect on other organs,so neonicotinoids cause hepatotoxicity ${ }^{(12)}$, nephrotoxicity ${ }^{(13)}$ and abnormalities blood indices (14)

\section{MATERIALS AND METHODS}

Chemicals: Two neonicotinoid insecticides:

1-Thiamethoxam insecticide (Pilot 25\%) is yellowish white crystalline powder insecticide and soluble in water and was purchased from Rotam Agrochemical Co Ltd-Egypt under of license of Rotam Agrochemical Co Ltd-Hong Kong.

2- Acetamiprid insecticide (Mospilan 20\%): is a water soluble $^{(15)}$ light blue fine powder without any odor and was purchased from Sumitomo CorporationSumitomo Corporation under license of NIPPON SODA CO., LTD- Tokyo- Japan.

Acute toxicity study: Approximate $\mathrm{LD}_{50}$ (Acetamiprid) in rats were determined according to method OECD ${ }^{(16)}$.

\section{Animals}

A total number of 45adultmaleSwissalbino rats, each weighed 90-110 g. The animals were maintainedin controlled environment of temperature, humidity, light, and fed on a commercial standard diet and tap water ad libitum. Experimental design: Animals were divided into 3 groups as follows: Group (1): Negative Control:
This group comprised 9 rats feed on normal diet and drunk normal water along period of the experiment. Group (2): Thiamethoxam group: This group comprised 18 rats, received Thiamethoxam insecticide orally at dose 156 $\mathrm{mg} / \mathrm{Kg}$ body weight (1/10 oral LD50) every day (17) along 30 days.

Group (3): Acetamiprid group: This group comprise 18 rats, received Acetamiprid insecticide orally at dose $100 \mathrm{mg} / \mathrm{Kg}$ body weight (1/10 oral LD50) in rats was dissolved in tap water and stirrer it to complete dissolving; every day for 30 days.

At the end of the experiment, animals were scarified every 10, 20 and 30 days (3 animals fromgroup1) and (6 animals of groups 2,3 ) for each time).Blood samples, liver, and kidney tissues were collected for hematological, biochemical and histopathological analysis.

\section{(A)Hematological studies}

Whole blood samples were evaluated for complete blood count (CBC) [RBCs, WBCs, PLts, Hb, Hct, $\mathrm{MCV}, \mathrm{MCH}$ and $\mathrm{MCHC}]$ using the complete blood cell counter (Abacus 380 CBC Counter).

\section{(B)Biochemical analysis}

\section{1- Liver function tests:}

The serum was prepared for liver function tests. Alanine transamines (ALT),asparatatetransamines (AST), total protein and albumin were determined by using Bio-diagnostic kit method according to the method of according to Schumann and Klauke, ${ }^{(18)}$, Karmenet al., ${ }^{(19)}$, Doumas, ${ }^{(20)}$ and Doumaset al., ${ }^{(21)}$ methods; respectively.

\section{2- Kidney function tests}

The serum was prepared for kidney function tests. Urea and creatinine were determined by using Bio-diagnostic kit method according to the method of according to Tabaacoet al., ${ }^{(22)}$ and Murray, ${ }^{(23)}$ methods; respectively.

\section{(C)Histopathological studies}

Histological evaluation was performed on other portion of the liver and kidney tissue. Specimen were fixed in $10 \%$ formalin and embedded in paraffin wax. Liver and kidney tissuessections were cut at $5 \mu \mathrm{m}$ in thickness, stained with hematoxylin and eosin (H\&E),viewed under light microscopy and examined the histological changes according to Lillie, ${ }^{(24)}$.

\section{(D)Statistical analyses}


Data were evaluated by one-way analysis of variance (ANOVA)by "SPSS" 14.0 for Microsoft Windows, SPSS Inc.Levesque, ${ }^{(25)}$ methodand considered statistically significant at a two-sided $\mathrm{P}$ $<0.05$. Numerical data were expressed as mean \pm SD.

\section{RESULTS}

Acute toxicity study: The acute toxicity was estimated by oral administration of the Acetamiprid determined the median lethal dose $\left(\mathrm{LD}_{50}\right)$ of it. Our results revealed that, doses up to $500 \mathrm{mg} / \mathrm{kg}$ were considered to be safe dose for extract, where no mortality was observed. As the selected dose was $100 \mathrm{mg} / \mathrm{kg}$ body weight.

Effect of Thiamethoxam and Acetamiprid on hematological parameters in serum in all studied groups:

Table (1)summarized the mean values of the hematological parameters $(\mathrm{Hb}, \mathrm{RBCs}, \mathrm{Hct}, \mathrm{MCV}$, $\mathrm{MCH}, \mathrm{MCHC}$, PLts and WBCs) were found to be $14.5 \pm 0.81(\mathrm{~g} / \mathrm{dl}), 7.0 \pm 0.44\left(\times 10^{6}\right.$ million $\left./ \mathrm{mm}^{3}\right), 41.9 \pm$ $2.5 \quad(\%), \quad 57.3 \pm 1.7(\mathrm{fl}), \quad 21.05 \pm \quad 0.81(\mathrm{pg})$, $33.8 \pm 1.0(\%), 543.1 \pm 19.6\left(\times 10^{3} \mathrm{~mm}^{3}\right)$ and $8.9 \pm 0.44$ $\left(\times 10^{3} \mathrm{~mm}^{3}\right)$ in negative control group.

In Thiamethoxam group, the hematological parameters(Hb, RBCs, Hct, MCV, MCH, MCHC and PLts) were demonstrated a gradually significant decrease to be $(10.6 \pm 0.26 \mathrm{~g} / \mathrm{dl}$, $9.03 \pm 0.40$ and $7.1 \pm 0.61)$ by $(26.0 \%, 37.7 \%$ and51.0\%);(5.3 $\pm 0.23 \times 10^{6} \quad$ million $/ \mathrm{mm}^{3}$, $4.08 \pm 0.24$ and $2.88 \pm 0.70)$ by $(24.7 \%, 41.7 \%$ and $58.8 \%) ;(34.7 \pm 1.91 \%, 26.51 \pm 1.6$ and $19.2 \pm 1.5)$ by $(17.2 \%, 37.7 \%$ and $54.2 \%) ;(44.8 \pm 4.8 \mathrm{fl}, 40.8 \pm 1.9$ and $29.4 \pm 2.0)$ by $(21.8 \%, 8.8 \%$ and $48.7 \%) ;(18.8 \pm 0.68 \mathrm{pg}, 17.08 \pm 0.19$ and $15.02 \pm 0.63)$ by $(10.7 \%, 18.9 \%$ and $28.9 \%)$; $(30.11 \pm 0.64 \%, 28.46 \pm 1.07$ and $28.38 \pm 1.3)$ by $(10.9 \%, 15.8 \%$ and $16.0 \%)$ and $\left(476.6 \pm 17.4 \times 10^{3} \mathrm{~mm}^{3}, 356.3 \pm 36.8\right.$ and $\left.175.3 \pm 22.1\right)$ by $(12.2 \%, 34.4 \%$ and $67.7 \%)$ respectively; compared to negative control group ( $\mathrm{p}<0.001)$. On the other hand; WBCs counts were showed a gradually significant increase to be $(11.11 \pm 0.62$ $\times 10^{3} \mathrm{~mm}^{3}, \quad 12.8 \pm 0.95$ and $\left.16.3 \pm 1.4\right)$ by $(24.8 \%$, $43.8 \%$ and $83.1 \%$ ) in Thiamethoxam group after 10,20 and 30 days respectively; compared to negative control group $(\mathrm{p}<0.001)$.

In Acetamiprid group, the hematological parameters $(\mathrm{Hb}, \mathrm{RBCs}$, Hct, MCV, MCH, MCHC and PLts) were revealed a gradually significant decrease to be $(12.2 \pm 0.25 \mathrm{~g} / \mathrm{dl}, 11.8 \pm 0.069$ and $10.03 \pm 0.44)$ by $(15.9 \%, 18.9 \%$ and $29.0 \%)$; $\left(6.1 \pm 0.26 \times 1^{6} \mathrm{million} / \mathrm{mm}^{3}, \quad 5.146 \pm 0.22 \quad\right.$ and $4.08 \pm 0.87)$ by $(12.9 \%, 21.1 \%$ and $41.7 \%) ;(38.8$ $\pm 0.60 \%, \quad 31.3 \pm 0.45$ and $28.54 \pm 1.6)$ by $(7.4 \%, 25.7 \%$ and $31.9 \%) ; \quad(48.25 \pm 3.8 \mathrm{fl}$, $38.01 \pm 127.2$ and $31.01 \pm 0.446)$ by $(15.8 \%, 33.7 \%$ and $45.9 \%) ;(20.1 \pm 0.47 \mathrm{pg}, \quad 17.08 \pm 0.19$ and $16.246 \pm 0.37)$ by $(4.5 \%, 17.4 \%$ and $23.0 \%) ;(31.7 \pm 0.4 \%, 17.39 \pm 0.659$ and $28.9 \pm 0.90)$ by $\quad(6.2 \%, \quad 48.6 \%$ and $14.5 \%)$ and $\left(495.0 \pm 28.0 \times 10^{3} \mathrm{~mm}^{3}, 371.3 \pm 12.56\right.$ and $279.00 \pm 19.7)$ by $(8.9 \%, 5.4 \%$ and $48.6 \%)$ respectively; compared to negative control group $(\mathrm{p}<0.001)$. On the other hand; WBCs counts are showed a gradually significant increase in WBCs counts to be $\left(11.11 \pm 0.62 \times 10^{3} \mathrm{~mm}^{3}, 12.8 \pm 0.95\right.$ and $16.3 \pm 1.4)$ by $(15.7 \%, 36.0 \%$ and $50.6 \%)$ in Acetamiprid group after 10, 20 and 30 days respectively; compared to negative control group $(\mathrm{p}<0.001)$.

Effect of Thiamethoxam and Acetamiprid on liver function tests in serum in all studied groups:

Table (2)summarized the mean valuesof liver functions tests (ALT, AST activities, total protein and albumin concentrations) were found to be 68.38 \pm 8.17 (U/L), $95.5 \pm 8.89$ (U/L), $9.0 \pm 0.79$ (g/l) and $4.16 \pm 0.30(\mathrm{~g} / \mathrm{l})$ in negative control group.

On a hand, ALT and AST activities were showed agraduallysignificant elevation to be $(121.75 \pm 3.37$ $\mathrm{U} / \mathrm{L}, \quad 233.66 \pm 4.85$ and $309.78 \pm 6.97)$ by $(78.0 \%$, $241.7 \%$ and $353.0 \%)$ and $(218.18 \pm 10.95 \mathrm{U} / \mathrm{L}$, $339.5 \pm 44.7$ and $482.35 \pm 13.14)$ by $(128.7 \%$, $255.1 \%$ and $405.0 \%$ ) in Thiamethoxam group; $(96.8 \pm 4.66 \mathrm{U} / \mathrm{L}, 233.66 \pm 4.85$ and $191.81 \pm 0.6)$ by $(41.6 \%, 241.7 \%$ and $180 \%)$ and $(187.38 \pm 5.1 \mathrm{U} / \mathrm{L}$, $339.5 \pm 44.7$ and $282.3 \pm 18.649)$ by $(96.1 \%$, $255.5 \%$ and $195.6 \%$ ) in Acetamiprid group respectively; after 10,20 and 30 days compared to the negative control $\operatorname{group}(\mathrm{p}<0.001)$.

On the other hand, total protein and albumin concentrationswere observed a significant reduction to be $(6.47 \pm 0.339 \mathrm{~g} / \mathrm{l}, \quad 5.1 \pm 0.02$ and $4.69 \pm 0.05)$ by $(28.1 \%, 43.3 \%$ and $47.9 \%)$ and $(3.41 \pm 0.058 \mathrm{~g} / 1,2.7 \pm 0.25 \mathrm{~g} / 1$ and $1.8 \pm 0.187)$ by $(18.0 \%, 35.1 \%$ and $56.7 \%)$ in Thiamethoxam group; $(7.3 \pm 0.27 \mathrm{~g} / 1,5.1 \pm 0.02$ and $5.6 \pm 0.06 \mathrm{~g} / \mathrm{l})$ by $(18.5 \%, 43.0 \%$ and $37.7 \%)$ and $(3.4 \pm 0.97 \mathrm{~g} / \mathrm{l}$, $2.7 \pm 0.27$ and $2.52 \pm 0.06)$ by $(18.3 \%, 35.1 \%$ and 
$39.9 \%$ ) in Acetamiprid group respectively after 10,20 and 30; compared to the negative control group $(\mathrm{p}<0.001)$.

\section{Effect of Thiamethoxam and Acetamiprid on kidney functions tests in serum in all studied groups:}

Table (3) summarized the mean values of kidneyfunctions (urea, and creatinine) in Thiamethoxam and Acetamiprid groups were observed to be $19.3 \pm 2.6(\mathrm{mg} / \mathrm{dl})$ and $0.62 \pm 0.08$ $(\mathrm{mg} / \mathrm{dl})$ in negative control group.

Urea and creatinine concentration were showed a gradually significant increase to be $(53.75 \pm 4.5$ $\mathrm{mg} / \mathrm{dl}, 65.66 \pm 2.67$ and $95.5 \pm 8.9)$ by $(187.2 \%$, $240.2 \%$ and $394.4 \%)$ and $(1.2 \pm 0.43 \mathrm{mg} / \mathrm{dl}$, $1.16 \pm 0.6$ and $2.4 \pm 0.36)$ by $(93.7 \%, 87.1 \%$ and $287.1 \%)$ in Thiamethoxam group; $(35.16 \pm 2.9$ $\mathrm{mg} / \mathrm{dl}, 45.87 \pm 2.5$ and $58.32 \pm 4.64)$ by $(82.2 \%$, $137.7 \%$ and $202.2 \%)$ and $(0.93 \pm 0.06 \mathrm{mg} / \mathrm{dl}, 1.49 \pm$ 0.34 and $1.89 \pm 4.64)$ by $(50.0 \%, 140.3 \%$ and $204.8 \%$ ) in Acetamiprid group after 10,20 and 30 days respectively; compared to the negative control group $(\mathrm{p}<0.001)$.

\section{Histological studies in all studied groups:}

The histological examinations of liver and kidney tissues with Hematoxylin and Eosin stain in the different studied groups confirmed the biochemical study in all different groups.

Negative control Groupnormal structure of hepatocytes and normal renal cells of kidney in Fig $(\boldsymbol{I A}, \boldsymbol{I I A})$. Liver and Kidney tissues of Thiamethoxam and Acetamipridtreated ratswere altered along experiment. Fig.(IB)revealed that dilated congestion in central vein filled with red blood cells surrounded by hepatocytes cells and vacuolatedcytoplasm of a rat treated Thiamethoxam insecticide after 10 days.Fig. (IC) showed that dilated congestion in central vein filled with red blood cells surrounded by hepatocytes cells with appearance area of necrosis of a rat treated Thiamethoxam insecticide after 20 days. Fig.(ID)demonstrated thatdilated congestion in central vein filled with red blood cells surrounded by hepatocytes cells and area of fibrosis and infiltertration inflammatory cells of a rat treated Thiamethoxam insecticide after 30 days.Fig.(IE) revealed that mild dilated congested central vein filled with red blood cells surrounded by hepatocytes cells and vacuolated cytoplasm of a rat treated Acetamiprid insecticide after 10 days.Fig. (IF) illustrated that mild dilation central vein filled with red blood cells surrounded by hepatocytes cells and central vein surrounded by aggregation of inflammatory cells of a rat treated Acetamiprid insecticide after 20 days.Fig. (IG) confirmed that mild dilated congestion in central vein filled with red blood cells surrounded by hepatocytes with area of necrosis of hepatocytes cells of a rat treated Acetamiprid insecticide after 30 days.

On the other hand, Fig. (IIB) illustrated that atrophic glomeruli and cloudy swelling in renal tubules of a rat treated Thiamethoxam insecticide after 10 days. Fig.(IIC) showed thatcloudy swelling in renal tubules with dilation of blood vessels and appearance a few aggregation of inflammatory cells in kidney of a rat treated Thiamethoxam insecticide after 20 days.Fig. (IID) indicated that an increase cloudy swelling in renal tubules, spreading atrophic glomeruli and more congestion of blood vessels with red blood cells in the interstitial space between the tubules and glomeruli of a rat treated Thiamethoxam insecticide after 30 day. Fig.(IIE) demonstrated that congestion in blood vessel with red blood cells and cloudy swelling in proximal and distal convoluted tubules of a rat treated Acetamiprid insecticide after 10 days. Fig.(IIF)revealed that hemorrhage, atrophic glomeruli, cloudy swelling and aggregation of inflammatory cells of a rat treated Acetamiprid insecticide after 20 days. Fig. (IIG) illustrated that small aggregation of inflammatory cells, congestion blood vessel, cloudy swelling in renal tubules and area of fibrosis in renal tubules of a rat treated Acetamiprid insecticide after 30 days.

\section{DISCUSSION}

Thiamethoxam (THIA), is one kind of neonicotinoidinsecticide thatinduced hematological alternations and changes in heart, liver, gonads as well as kidneys tissues in mice ${ }^{(26)}$. Acetamiprid is a synthetic chlorinated nicotimine pesticide, is an agonist of the nicotinic acetylcholine receptor that induces neuromuscular paralysis and eventually causes death (27). Acetamiprid is hepatotoxic and nephrotoxic, in goats ${ }^{(28)}$. 
Our data after 10, 20, and 30 days in THIA and AC groups ( $\mathrm{Hb}, \mathrm{RBCs}$, WBCs, PLts, Hct, MCV, $\mathrm{MCH}$, and $\mathrm{MCHC}$ ) showed the hematological alterations. In Thiamethoxam group ( $\mathrm{Hb}, \mathrm{RBC}$, Hct, MCV, MCH, MCHC and Plts) values decreased by $(26.0 \%, 37.7 \%$ and $51.0 \%),(24.7 \%$, $41.7 \%$ and $58.8 \%),(17.2 \%, 37.7 \%$ and $54.2 \%$ )$,(21.8 \%, 28.8 \%$ and $48.7 \%),(10.7 \%, 18.9 \%$ and $28.9 \%),(10.9 \%, 15.8 \%$ and $16.0 \%)$ and $(12.2 \%$, $34.4 \%$ and $67.7 \%$ ) respectively; compared to negative control group $(\mathrm{p}<0.001)$. On the other hand; the mean value of WBC counts increased $(\mathrm{p}<0.001), \quad$ by $24.8 \%, \quad 43.8 \%$ and $83.1 \%$ respectively; compared to negative control group. Our study showed that $(\mathrm{Hb}, \mathrm{RBCs}$, WBCs, PLts, $\mathrm{Hct}, \mathrm{MCV}, \mathrm{MCH}$, and $\mathrm{MCHC}$ ) in Acetamiprid group. (Hb, RBC, Hct, MCV; MCH,MCHC and Plts)value reduced by $(15.9 \%, 18.9 \%$ and $29.0 \%),(12.9 \%, 21.1 \%$ and $41.7 \%),(7.4 \%, 25.7 \%$ and $31.9 \%),(15.8 \%, 33.7 \%$ and $45.9 \%),(4.5 \%$, $17.4 \%$ and $23.0 \%),(6.2 \%, 48.6 \%$ and $14.5 \%)$ and $(8.9 \%, 5.4 \%$ and $48.6 \%)$ respectively; compared to negative control group $(\mathrm{p}<0.001)$. On the other hand; WBC counts increased $(\mathrm{p}<0.001)$, by $15.7 \%$, $36.0 \%$ and $50.6 \%$ respectively; compared to negative control group.

THIA and AC insecticides reducedin RBCs count and hemoglobin concentration in blood that may be failure in red cell production and/or due to increase in the erythrocyte destruction and this probably was responsible for a decrease in $\mathrm{Hb}$ concentration that indicates anemia by these insecticides. Also, Hct, MCV, $\mathrm{MCH}$ and $\mathrm{MCHC}$ values could probably decrease due to stress induced by insecticides and the occurrence of haemolytic anemia which exaggerates further disturbances in haemopoietic activities ${ }^{(29)}$.In fact, haemoglobinlevel and haematocrit values are directly correlated with RBC's count ${ }^{(30)}$. But increase in WBCs countmay be occurred as a pathological response as these cells play a great role during infestation by stimulating the haemopoietic tissues and the immune system by producing antibodies due to stress of THIA and $\mathrm{AC}{ }^{(31)}$. The increase in WBC may be indicating the activation of defense and immune system of the body ${ }^{(32)}$. Nicotine that main unit of THIA and $\mathrm{AC}$ induced an elevation in WBC due to prompt inflammation ${ }^{(33)}$ and reductionRBCs count because nicotine induced hypoxia in red blood cells and effected on passage of oxygen to tissue. Also, stress can alter the function of the white blood cells involved in immune function known as lymphocytes and macrophages ${ }^{(34)}$.

Reduction of platelets count may be occurred as a result of damage in coagulation process and haemostasis blood system ${ }^{(35)}$. Inhibitory actions of THIA and AC on immune and haematopoietic systems might also be responsible for thymicatrophy and hypo cellularity in the bone marrow that reduced levels of Plts ${ }^{(36)}$. Our finding were in agreement withmany authorsVohra and Khera ${ }^{(37)}$ who showedimidacloprid, neonicotinoid, caused reduction in platelet count and disturbed blood clotting.Gawadeet al., ${ }^{(38)}$ reported that imidacloprid reduced in $\mathrm{Hb}$ content may be due to increased rate of breakdown of red cells and/or reduction in the rate of formation of RBC's ${ }^{(39)}$. Furthermore, Singh et al., ${ }^{(40)}$ who suggested that acetamiprid in mice decreased $\mathrm{Hb}$ levels. Our finding agreement with Roy and Nath, ${ }^{(41)}$ who showed that THIA caused reduction in RBCs count and $\mathrm{Hb}$ level due to the destruction of RBCtriggered by the arrival of THIA into erythrocytes, and WBCs increase during higher doses of THIA attributed to the production of a greater amount of antibodies ${ }^{(42)}$.

Liver function tests in studied groups after 10, 20, and 30 days of THIA and AC administrationsrecorded a significant increase in ALT and AST activity. In thiamethoxam group ALT and AST increased by $(78.0 \%, 241.7 \%$ and $353.0 \%)$ and $(128.7 \%, 255.1 \%$ and $405.0 \%)$; respectively. But total protein and albumin concentrations declined by $(28.1 \%, 43.3 \%$ and $47.9 \%)$ and $(18.0 \%, 35.1 \%$ and $56.7 \%)$ respectively $(\mathrm{p}<0.001)$; compared to negative control group. AC group revealed a significant increase in ALT andAST activities along ofperiod10, 20, 30 days by $(41.6 \%, 241.7 \%$ and $180 \%)$ and $(128.7 \%, 255.1 \%$ and $405.0 \%)$; respectively. But total protein and albumin concentrations reducedby $(18.5 \%, 43.0 \%$ and $37.7 \%)$ and $(18.3 \%, 35.1 \%$ and $39.9 \%)$ by respectively; compared to the negative control group. These biochemical alterations in liver were confirmed by histological examinations such as congestion in central vein, fatty change, and inflammation and hepatocytes necrosis at 10, 20, and 30 days in both treatments. 
As, liver is a predominant organ for the metabolism, and also is the center detoxifying any foreign compounds entering the body ${ }^{(43)}$.

The damage in liver in treated rats by THIA and AC may be due to increased permeability of cell membrane, resulting in release of transaminases in the blood stream and caused necrosis of hepatocytes ${ }^{(44)}$, leading to impaired synthesis of many coagulation factors and their inhibitors that caused congestion blood vessels. While, the decreasing in total protein and albumin concentrations may be occurred due to disturbance in protein metabolism as a result of reduction in protein synthesis or elevationproteolytic activity or degradation $^{(45)}$. The increase in level of specific enzymes correlates with the gross and histopathological changes in liver observed in present investigations. Our results were in a line with Vohraet al., ${ }^{(46)}$ who suggested that imidacloprid,neonicotinoid, increasedAST, ALT enzymes activities in rats and causedmarked congestion of central vein and degeneration of hepatocytes. Jiao-jiaoet al., ${ }^{(47)}$ showed that AC increased AST and ALT in mice. This gave further evidence that the detrimental effects of $\mathrm{AC}$ were mediated disturbance in the biosynthesis of these enzymes with alteration in the permeability of liver membrane takes place ${ }^{(48)}$. Moreover, our data agreed with Shalabyet al., ${ }^{(49)}$ who showed that there are residual traces of THIA on were determined in liver after 10 days, increased in the activity of ALT at 5and 10 days of administration due to the leakage enzyme from damaged membranes. Also, Al-Sharqiet al., ${ }^{(50)}$ showed different pathological lesions in the liver tissue such as disturbed of the hepatic lobule structure, hepatocytes hypertrophy with inflammatory cells infiltration, kupffer cells proliferation, coagulates necrosis and hydropic degeneration after the 15 and 30 days of THIA treatment that used 0.2, 0.4, 0.8 and $1.6 \mathrm{mg} / \mathrm{kg}$ of body weight and these histological changes were leveled sever according to the dosage and the duration. Soujanyaet al., ${ }^{(51)}$ showed that imidacloprid over 4 weeks increased AST and ALT activities in ratsas their higher activities are specific indicators of liver cell damage such as necrotic changes in the liver.

Kidney function tests (urea and creatinine) after 10,20, 30 days in THIA treated group showed a significant increase in urea and creatinineby $(187.2 \%, 240.2 \%$ and $394.4 \%)$ and $(93.7 \%, 87.1 \%$ and $287.1 \%$ ). Similarly, AC treated group they increased by $(82.2 \%, 137.7 \%$ and 202.2$)$ and (50.0\%,140.3\% and 204.8\%); after 10, 20 and 30 daysrespectively compared to the negative control group. These biochemical elevation were confirmed by histopathological examinations as cleared atrophic glomeruli and cloudy swelling in renal tubules, few aggregation of inflammatory cells, occurred fibrosis in renal cells, spreading atrophic glomeruli and more congestion of blood vessels in the interstitial space between the tubules and glomeruli in kidney tissues in both treatments. As, kidney is an organ sensitive to external factors such as administration of insecticides. In addition to,serum creatinine and urea concentrations have been usually used to diagnose impaired kidney function and to detect renal damage ${ }^{(52)}$. The change in kidney functions may be resulted from direct effect of THIA and AC or their metabolites on renal cells and indirectly by alterations in renal hemodynamics ${ }^{(53)}$. Nicotine induced glomerular dysfunction and proteinuria ${ }^{(54)}$. In renal damage, there are increased fluids in the body leading to cloudy swelling as increased acid levels, raised levels of potassium, decreased levels of calcium, increased levels of phosphate, and in later stages anemia.Moreover, kidney damage impaired hemostasis due to platelet dysfunction and caused hemorrhageand caused congestion of blood vessels in the interstitial space between the tubules and glomeruli ${ }^{(55)}$.

These results were in accordance to many authors Bhardwajet al., ${ }^{(56)}$ who showed that, imidacloprid caused significant elevated levels of blood urea nitrogen (BUN) together with tubular changes in the kidney due to its nephrological effect andthe elevation of protein catabolism in the mammalian body. It may also result due to a more efficient conversion of ammonia to urea. Goyalet al., ${ }^{(57)}$ suggested thatthiacolprid, neonicotinoidcaused marked congestion, tubular cell degeneration and sloughing of epithelial cells. As a result of its accumulation in liver and excretion through kidney, it caused indirectly alterations in renal haemodynamics, or by a combination of both. Al-Sharqiet al., ${ }^{(50)}$ found that, histopathological lesions in the kidney included hemorrhage areas in the interstitial 
space between the tubules as well as glomeruli, congested blood vessels associated with thickened wall and aggregation of inflammation cells in kidney sections of THIA treated after 15 and 30 days at $0.2,0.4,0.8$ and $1.6 \mathrm{mg} / \mathrm{kg}$ of body weight of THIA.

Moreover, Shalabyet al., ${ }^{(49)}$ showed THIAproduced hemorrhage areas and cloudy swelling in the renal tubulesthrough 5,10 days of its administration. Moreover, lobulation in the glomeruli and congested blood vessels associated with thickened wall observed in kidney sections of Thiamethoxam treated rats. Additionally, the creatinine concentration recorded a significant increase after 10 days of treatment.

Therefore, our data proved the high toxic effects (hepatotoxic, and nephrotoxic) induced by THIA more than theses induced by AC.

\section{Conclusion:}

It can be concluded that, Thiamethoxam and Acetamiprid are hepatotoxic, nephrotoxic compounds and also they induce hematological and histopathological alterations in blood and tissues. So, the uses of these insecticides should be limited.

\section{REFERENCES}

1. Bingham G., Gunning R.V., Delogu G., Borzatta V., Field L.M. andMoores G.D., (2008): Temporal synergism can enhance carbamate and neonicotinoid insecticidal activity against resistant crop pests. J. Pest. Manage.Sci., 64 (5): 81-88.

2. Duan H., Zhang W., Zhao J., Liang D., Yang $X$. and Jin S.,(2012): A novel halogen bond and a better-known hydrogen bond cooperation of neonicotinoid and insect nicotinic acetylcholine receptor recognition. J.Mol. Model.,18(8):3867-3875.

3. OhnoI., Tomizawa M., Aoshima A., Kumazawa S. and Kagabu S.,(2010): Trifluoroacetylneonicotinoid insecticides with enhanced hydrophobicity and effectiveness.J.Agric Food Chem,58: 4999.

4. Zhou G., Wang Y., Zhai S., Ge F., Liu Z., Dai Y., Yuan S. and Hou J.,(2013): Biodegradation of the neonicotinoid insecticide thiamethoxam by the nitrogen-fixing and plantgrowth-promoting rhizobacteriumEnsiferadhaerensstrain TMX-23. J.ApplMicrobiolBiotechnol, 97: 4065-4074.
5. Zhang Y., Zhang G., Zhou $X$. and Li Y.,(2013): Determination of acetamiprid partialintercalative binding to DNA by use of spectroscopic, chemometrics, and molecular docking techniques.J.Anal Bioanal Chem., 405(27):8871-8388.

6. Ford K.A. and Casida J.E., (2006):Unique and common metabolites of thiamethoxam, clothianidin, and dinotefuran in mice. J. Chem. Res. Toxicol., 19(11) : 1549-155 .

7. Green T., Toghill A., Lee R., Waechter F., Weber E. andNoakes J., (2005):Thiamethoxam induced mouse liver tumors and their relevance to humans. Part 1: mode of action studies in the mouse. J.Tox. Sci., 86(1): 36-47.

8. Wallace D.R.,(2014):Acetamiprid. Encyclopedia of Toxicology (Third Edition), 3032.

9. WHO (World Health Organization), (2011):Joint FAO-WHO meeting on Pesticide residues in food -Evaluations.2011. Available online:

http://apps.who.int/iris/bitstream/10665/75147/1/ 9789241665278_eng.pdf.

10. JMPR, (2011): Joint FAO/WHO Meeting on Pesticide Residues. Acetamiprid,3-92.

11. Kimura-Kuroda J., Komuta Y., Kuroda Y., Hayashi M. and Kawano H., (2012): Nicotine-Like Effects of the Neonicotinoid Insecticides Acetamiprid and Imidacloprid on Cerebellar Neurons from Neonatal Rats.J. PLoS ONE, 7(2): 32432.

12. Ivanova R., Hristev H. and Hoha G.V., (2013): Study on the effect of Actara and Confidoron birds submit to chronic intoxification. UASVM Iaşi J., LucrăriŞtiinţificeSeria Zootehnie, 60:244-246.

13. Bagri P., Kumar V., Sikka A.K. and Punia J.S., (2013): Preliminary acute toxicity study on imidacloprid in Swiss albino mice, J. Vet. World, 6(12): 955-959.

14. Rizwan-Ul-HAQ M., Sabri M.A. and Rashid A., (2005): Toxicity of nicotinylinsecticides on the haemocytes ofred cotton bug, Dysdercuskoenigii (Fb.) (Pyrrhocoridae: Hemiptera). JASS, 1: 3.

15. Tang H., Li J., Hu H., and Xu P., (2012): A newly isolated strain of Stenotrophomonas sp. hydrolyzes acetamiprid, a synthetic insecticide. $J$. J.Process Biochem.,47(12): 1820-1825. 
16. OECD (1992) :Guideline for Testing of Chemicals. No. 420:Acute Oral Toxicity--Fixed Dose Method. Organisationfor Economic Cooperation and Development, Paris.

17. MaienfischP., Angst M., Brandl F., Fischer W., Hofer D., Kayser H., Kobel W., Rindlisbacher A., Senn R., Steinemann A. and Widmer H., (2001): Chemistry and biology of thiamethoxam:a second generation neonicotinoid,J. Pest Manag Sci.,57(10):906-913. 18. Schumann G. and Klauke R., (2003): New IFCC reference procedures for the determination of catalytic activity concentrations of five enzymes in serum: preliminary upper reference limits obtained in hospitalized subjects. J. Clin. Chim. Acta., 327: 69-79.

19. Karmen A., Wroblewski F. and LaDue I.S.,(1955): Transaminase activity in human blood. J.Clin Invest.,34:126.

20. Doumas B.T., (1975): Standard methods of protein determination. J. Clin. Chem., 7: 175-188. 21. Doumas B.T., Watson W.A., and Biggs H.G., (1971): Albumin standards and the measurement of serum albumin with bromocresol green. J. Clin. Chem., 31: 87 - 96.

22. Tabacco A. Meiattini F., Moda E., and Tarlip P., (1979): Simplified enzymatic colorimetric serum urea nitrogen determination. J. Clin. Chem.,25:336-337.

23. Murray R.L., (1984):Creatinine. Kaplan A et al. ClinChem the C.V. Mosby Co. St Louis. Toronto. Princeton, 1261-1266.

24. Lillie R.D., (1976):Histopathologic technique. Practical Histochemistry. 95: 851-859. 25. Levesque R. SPSS., (2007): Programming and Data Management: A Guide for SPSS and SAS Users, Fourth Edition, SPSS Inc., Chicago Ill.

26. JMPR (2010): Joint FAO/WHO Meeting on Pesticide Residues (JMPR) at the request of the Codex Committee on Pesticide Residues (CCPR). Thiamethoxam, 565-676.

27. Mohamed F., Gawarammana I., Robertson T.A., Roberts M.S., Palangasinghe C., Zawahir S., Jayamanne S., Kandasamy J., Eddleston M., Buckley N.A., Dawson A.H. and Roberts D.M.,(2009): Acute human selfpoisoning with imidacloprid compound: a neonicotinoid insecticide. J.PLoS One, 4: e5127.
28. Chakraborty A., (2007): Deposition Kinetics and long term effect of acetamiprid (Insecticide) after oral administration in Black Bengal Goats. M.V.Sc.Thesis submitted to West Bengal University of Animal and Fishery Sciences, Kolkata, India.

29. Chen X., Yin D., Hu S.and Hou Y., (2004): Immunotoxicityof pentachlorophenol on macrophage immunity and IgM secretion of crucian carp (Carassiusauratus). J. Bull. Environ. Contam.Toxicol.,73:153-160

30. El-Bakary A.S., Abdel-Gawad A.F., ElMofty M.M. and Attia S.I., (1995) :Effect of dimethoate on some haematological parameters of toadBuforegularis. J. King Saud Univ.,7: 8593.

31. Lebelo S.L., Saunders D.K. and Crawford T.G., (2001): Observations on Blood Viscosity in Striped Bass, Moronesaxatilis (WalbaumAssociated with Fish Hatchery Conditions. J. Kansas Acad. Sci., 104: 183-194.

32. Yousef M.I., El-Demerdash F.M., Kamel K.I. and Al-Salhen K.S. (2003): Changes in some hematological and biochemical indices of rabbits induced by isoflavones and cypermethrin. J. Toxicol., 189(3) 223-234.

33. Chang E., Forsberg C.E. and Cooke J. P.,(2010):Cholinergic activation of hematopoietic stem cells. Vascular medicine (London, England),15(5):375-385.

34. Kalat J.W.,(2013): Biological Psychology. 381.

35. Abbes, S., Ouanes, Z., Ben S. J., Houas Z., Oueslati R., Bacha H., Othman O., (2006): The protective effect of hydrated sodium calcium aluminosilicate against haematological, biochemical and pathological changes induced by Zearalenone in mice. J. Toxicon., 47, 567574.

36. Saoudia M., Messarah M., Boumendjel A., Jamoussi K. and El Feki A.,(2011): Protective effects of vitamin $\mathrm{C}$ against haematological and biochemical toxicity induced by deltamethrin in male Wistar rat.J.Ecotoxicol. Environ. Saf.,74:1765-1769.

37. Vohra P. and Khera K.S. (2013): Effect of Imidacloprid on Plasma and Tissue Biochemistry of Albino rat. Indian J.Appl Res., 3:12.

38. Gawade L. , Dadarkar S.S., Husain R. and Gatne M., (2013):A detailed study of 
developmental immunotoxicity of imidacloprid in Wistar rats, J. Food ChemToxicol.,51: 6170.

39. Mossa A.H., (2004): Genotoxicity of pesticides. Ph.D. Thesis, Pesticide Chemistry and Toxicology, Faculty of Agriculture, Damanhour, Alexandria University.

40. Singh T.B.M.,Sunit K., Sar T.K. and Ganguly S., (2012): Acetamiprid Induces Toxicity in Mice under Experimental Conditions with Prominent Effect on the Hematobiochemical Parameters. J. Drug MetabToxicol.,3(6):134-138.

41. Roy B. and Nath S.,(2011): Some haematological investigations on Oreochromisniloticus (Trewavas) following exposure to Thiamethoxam. $J$. ActaZoologicaLituanica,21(4):1648-6919.

42. Spielman B.,(2004): Structure and function of the blood.Petplace. com Ed. Rhea Morgan.

43. Marrs T. C.,(2012):Mammalian Toxicology of Insecticides.JRSC,205-207.

44. Sathiavelu J.,Senapathy G.J., Devaraj R. and Namasivayam N., (2009): Hepatoprotective effect of chrysin on prooxidant-antioxidant status during ethanol-induced toxicity in female albino rats. J. Pharm Pharmacol., 61, 809-817.

45. Uboh F.E., Akpanabiatu M.I., Alozie Y., Edet E.E., Ndem J.I. and Ebong P.E., (2009):Comparative effect of vitamins $A$ and $\mathrm{E}$ on gasoline vapours induced haematotoxicity and weight -loss in male rats. Int. J. Pharmacol., 5: 215-221.

46. Vohra P., Khera K.S. and Sangha G.K., (2014): Physiological, biochemical and histological alterations induced by administration of imidacloprid in female albino rats. $J$. PesticBiochem Physiol., 110:50-56.

47. Jiao-jiao Z., Yi W., Hai-yang X., Mengxue L., Wen-hao L., Kai-ge M., Xian-zhong W. and Jia-hua Z., (2011): Oxidative Stress: role in acetamiprid-induced impairment of the male mice reproductive system. J. AgricSci China, 10(5): 786-796 .
48. Khan S.M., R.C. Sobti and L. Kataria, (2005): Pesticide-induced alteration in mice hepato-oxidative status and protective of black tea extract. J. Clin. Chim. Acta, 358: 131-138.

49. Shalaby S. EM., Farrag A. R. H. and ElSaed G. SM.,(2010): Toxicological potential of thiamethoxam insecticide on albino rats and its residues in some organs.JASMR, 5(2): 165-172.

50. Al-Sharqi S.A.H., Alwan M.J. and AlBideri A.W.,(2012): Histological Changes induced by the action of actara $25 \mathrm{wg}$ insecticides in mice. IJABR,2(4): 760-765.

51. Soujanya S., Lakshman M., Anand K. A. and Gopala R. A., (2012):Histopathological and ultrastructural changes induced by imidacloprid in brain and protective role of vitamin $\mathrm{C}$ in rats. J.Chem Pharm Res., 4(9) : 4307-4318.

52. Toffaletti J. G. and Mcdonnell E. H., (2008): Variation of serum creatinine, cystatin $C$ and creatinine clearance tests in persons with normal renal function. J.ClinicaChimicaActa., 395:115-119.

53. Shridhar N. B. ,(2010): Toxicity of Imidacloprid in Buffaloes. Indian J.AnimSci Res., 44:(3).

54. Cooper R.G., (2006): Effect of tobacco smoking on renal function. Indian J. Med Res., 124(3):261-268.

55. Kaw D. and Malhotra D.,(2006): Platelet dysfunction and end-stage renal disease. J.Semin Dial.,19(4):317-22.

56. Bhardwaj S., Srivastava M.K., Kapoor U. and Srivastava L.P., (2010): 90 days oral toxicity of imidacloprid in female rats: Morphological,biochemical and histopathological evaluations.J. Food ChemToxicol., 48: 11851190

57. Goyal S., Sandhu H. S. and Sandhu R. S., (2010): Histopathological alterations induced after oral sub-acute thiacloprid toxicity in Gallus domesticus. J.VeterinarskiArhiv., 80 (5): 673682. 
Table (1): The mean values of complete blood count The mean values of complete blood count: RBCs $\left(\times 10^{6} \mathrm{million} / \mathrm{mm}^{3}\right), \mathrm{WBCs}\left(\times 10^{3} \mathrm{~mm}^{3}\right), \mathrm{Hb}(\mathrm{g} / \mathrm{dl})$, PLts $\left(\times 10^{3} \mathrm{~mm}^{3}\right)$, Het $(\%)$, MCV $(\mathrm{fl}), \mathrm{MCH}(\mathrm{pg})$ and MCHC (\%) in Thiamethoxam and Acetamiprid groups

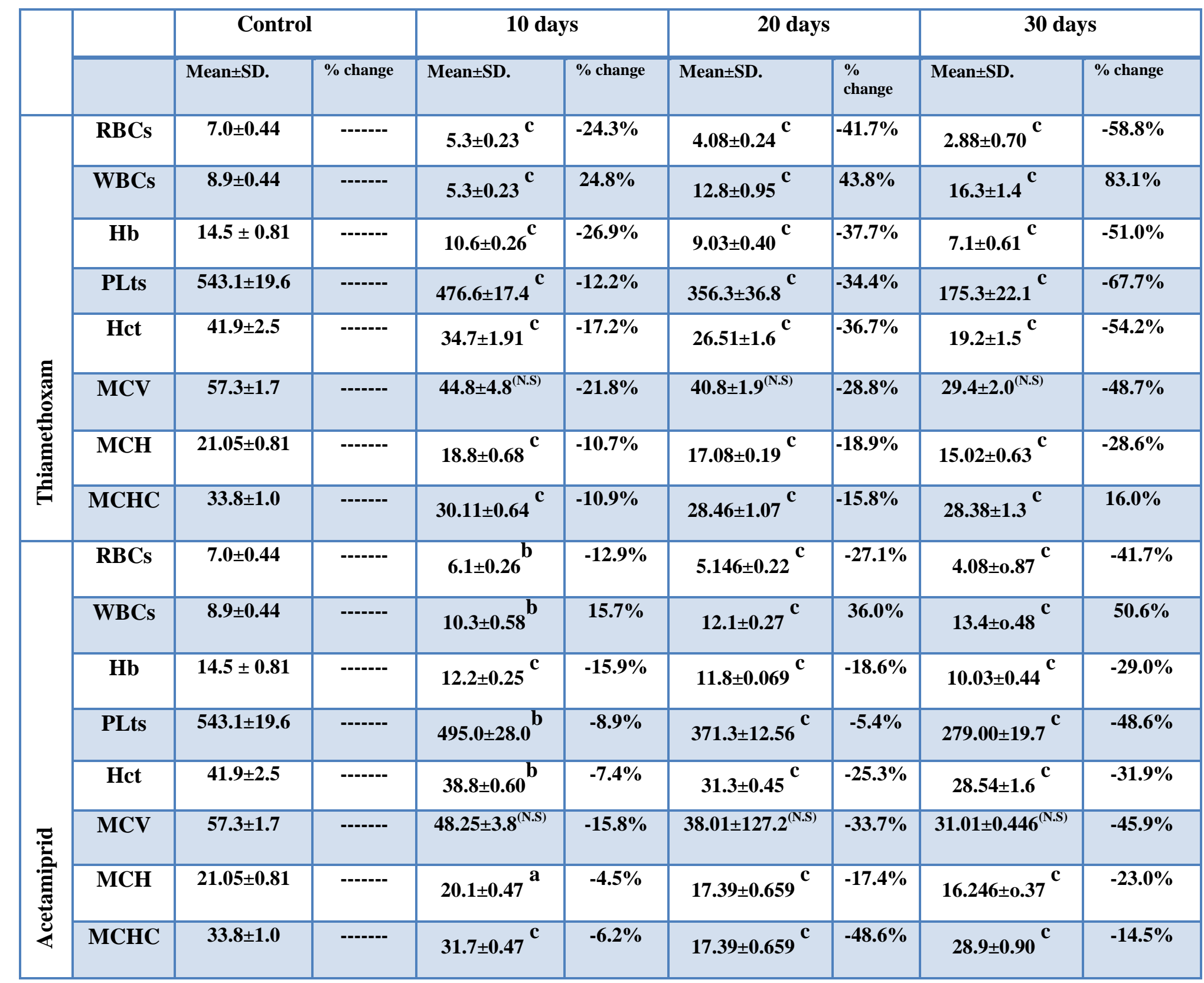

p: Significant difference when compared to negative control group. (N.S): Non-significant (P>0.05); (a)

Significant: $(\mathrm{P}<0.05)$; (b) Highly significant $(\mathrm{P}<0.01)$; (c) very highly significant: $(\mathrm{P}<0.001)$. 
Table(2): The mean values of liver functions: ALT (U/L), AST (U/L), Total Protein (g/l) and Albumin (g/l)) in Thiamethoxam and Acetamiprid groups

\begin{tabular}{|c|c|c|c|c|c|c|c|c|c|}
\hline & & \multicolumn{2}{|c|}{ Control } & \multicolumn{2}{|c|}{10 days } & \multicolumn{2}{|c|}{20 days } & \multicolumn{2}{|c|}{30 days } \\
\hline & & Mean \pm SD. & $\begin{array}{c}\% \\
\text { change }\end{array}$ & Mean \pm SD. & $\begin{array}{c}\% \\
\text { change }\end{array}$ & Mean \pm SD. & $\begin{array}{c}\% \\
\text { change }\end{array}$ & Mean \pm SD. & $\begin{array}{c}\% \\
\text { change }\end{array}$ \\
\hline \multirow{4}{*}{ 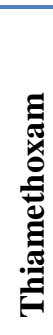 } & ALT & $68.38 \pm 8.17$ & ------ & $121.75 \pm 3.37^{c}$ & $78.0 \%$ & $233.66 \pm 4.85^{c}$ & $241.7 \%$ & $309.78 \pm 6.97^{c}$ & $353.0 \%$ \\
\hline & AST & $95.5 \pm 8.89$ & -------- & $218.18 \pm 10.95^{c}$ & $128.5 \%$ & $339.5 \pm 44.7^{c}$ & $255.1 \%$ & $482.35 \pm 13.14^{c}$ & $405.01 \%$ \\
\hline & Total Protein & $9.0 \pm 0.79$ & -.---.- & $6.47 \pm 0.339^{c}$ & $-28.1 \%$ & $5.1 \pm 0.02^{c}$ & $-43.3 \%$ & $4.69 \pm 0.05^{c}$ & $-47.9 \%$ \\
\hline & Albumin & $4.16 \pm 0.30$ & ------ & $3.41 \pm 0.058^{c}$ & $-18.0 \%$ & $2.7 \pm 0.25^{c}$ & $-35.1 \%$ & $1.8 \pm 0.187^{c}$ & $-56.7 \%$ \\
\hline \multirow{4}{*}{ 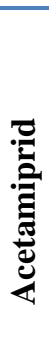 } & ALT & $68.38 \pm 8.17$ & ------ & $96.8 \pm 4.66^{c}$ & $41.6 \%$ & $233.66 \pm 4.85^{c}$ & $241.7 \%$ & $191.81 \pm 0.69^{c}$ & $180 \%$ \\
\hline & AST & $95.5 \pm 8.89$ & ------- & $187.38 \pm 5.1^{\mathrm{c}}$ & $96.1 \%$ & $339.5 \pm 44.7^{c}$ & $255.5 \%$ & $282.3 \pm 18.649^{c}$ & $195.6 \%$ \\
\hline & Total Protein & $9.0 \pm 0.79$ & ------ & $7.3 \pm 0.27^{c}$ & $-18.9 \%$ & $5.1 \pm 0.02^{c}$ & $-43.0 \%$ & $5.6 \pm 0.06^{c}$ & $-37.7 \%$ \\
\hline & Albumin & $4.16 \pm 0.30$ & ------- & $3.4 \pm 0.97^{c}$ & $-18.3 \%$ & $2.7 \pm 0.27^{c}$ & $-35.1 \%$ & $2.52 \pm 0.06^{c}$ & $-39.9 \%$ \\
\hline
\end{tabular}

p: Significant difference when compared to negative control group. (N.S): Non-significant $(\mathrm{P}>0.05)$; (a) Significant: $(\mathrm{P}<$ $0.05)$; (b) Highly significant $(\mathrm{P}<0.01)$; (c) very highly significant: $(\mathrm{P}<0.001)$.

Table(3): The mean values of kidney functions: urea $(\mathrm{mg} / \mathrm{dl})$ and creatinine $(\mathrm{mg} / \mathrm{dl})$ in Thiamethoxam and Acetamiprid groups

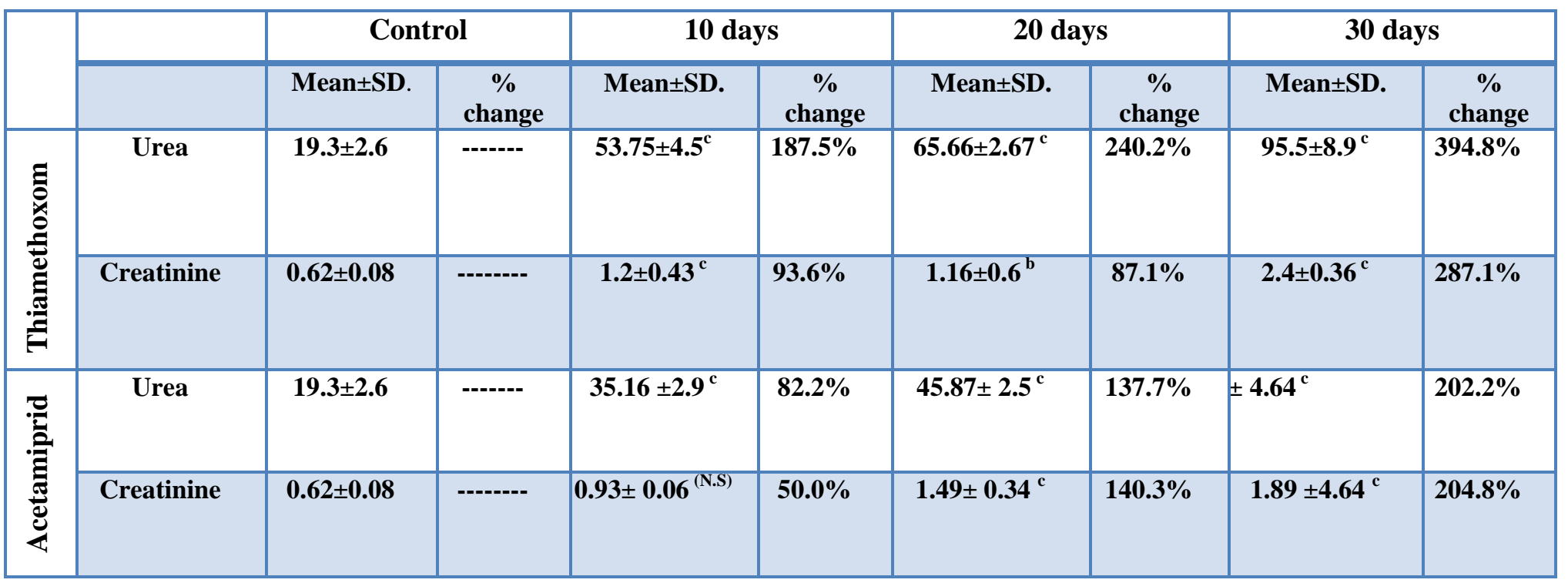

p: Significant difference when compared to negative control group. (N.S): Non-significant (P>0.05) ; (a) Significant: (P< $0.05)$; (b) Highly significant $(\mathrm{P}<0.01)$; (c) very highly significant: $(\mathrm{P}<0.001)$. 

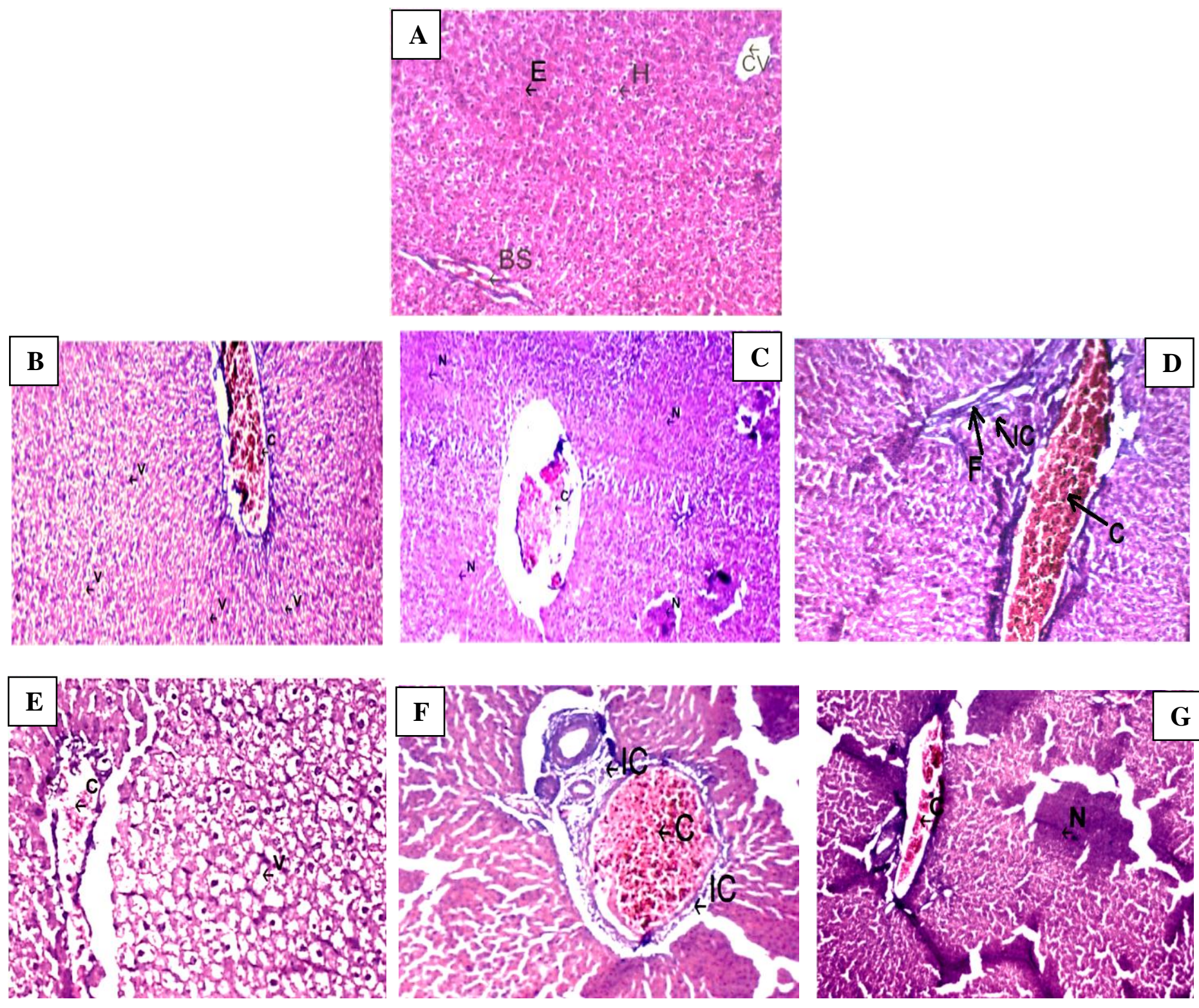

Fig .(I):A: Aphotomicrograph of liver of negative control rat show normal structure consisting of the central vein (CV) surrounded by rows and cords of hepatocytes $(\mathbf{H})$ with central nucleus, blood sinusoids (BV) and eosinophilic cytoplasm (E).B:Thiamethoxaminsecticide after 10days showing dilated congestion in central vein (C) filled with red blood cells surrounded by hepatocytes cells and vacuolated cytoplasm (V).C:Thiamethoxam insecticide after 20 days showing dilated congestion central vein $(\mathbf{C})$ filled with red blood cells surrounded by hepatocytes cells with area of necrosis (N).D:Thiamethoxam insecticide after $\mathbf{3 0}$ days showing dilated congestion in central vein(C) filled with red blood cells surrounded by hepatocytes cells, appearance area of fibrosis(F) and infiltration inflammatory cells(IC).E:Acetamiprid insecticide after10 days showing mild dilated congestion in central vein (C)filled with red blood cells surrounded by hepatocytes cells and vacuolated cytoplasm (V).F : Acetamiprid insecticide after 20 days showing mild dilated congestion in central vein (C) filled with red blood cells surrounded by hepatocytes cells and appearanceaggregation of inflammatory cells (IC).G: Acetamiprid insecticideafter 30 days showing mild dilated congestion in central vein (C)filled with red blood cells surrounded by hepatocytes with appearancearea of necrosis $(\mathbf{N})$ of hepatocytes cells $(\mathbf{H \& E}, \mathbf{X 2 0 0})$. 

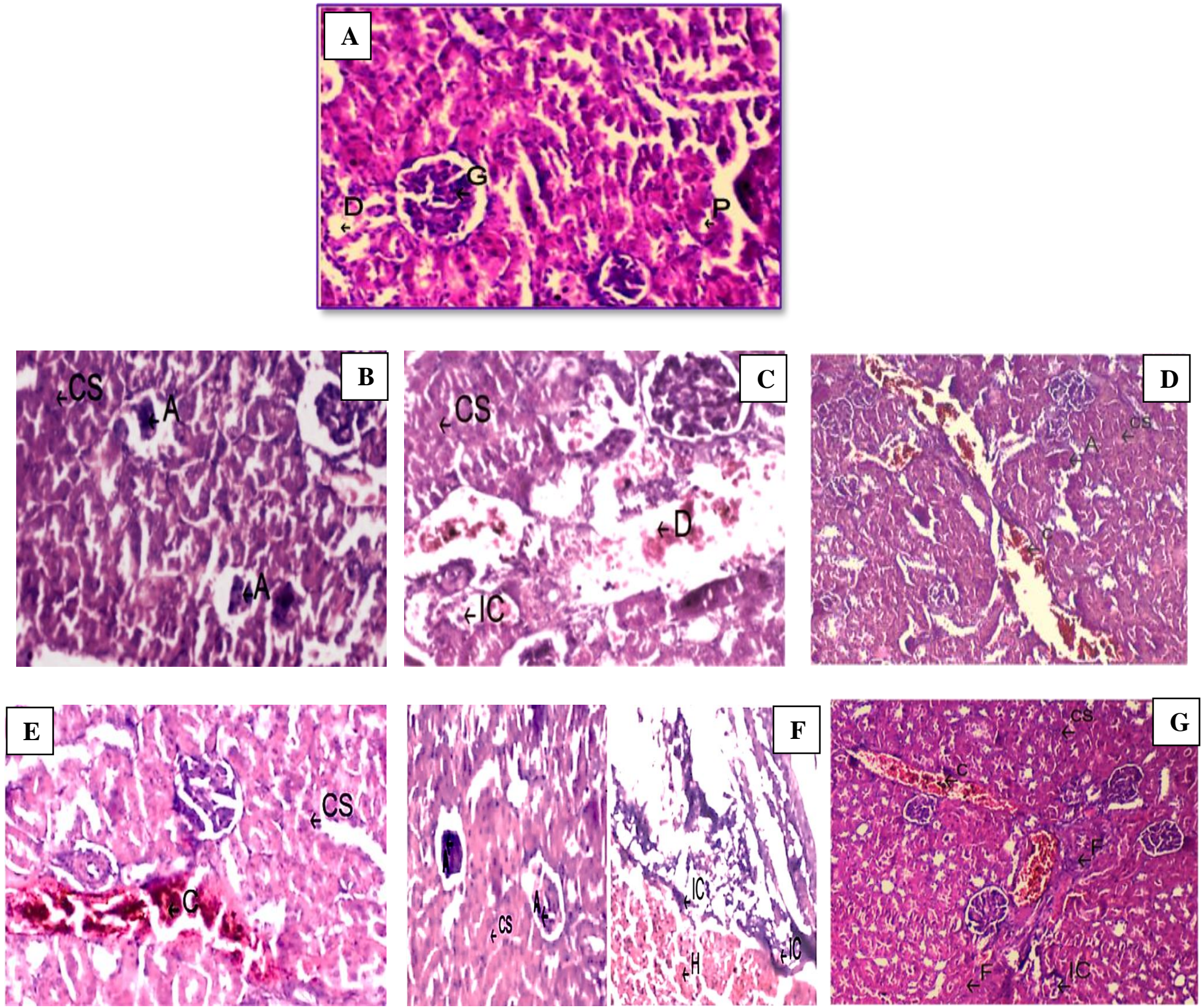

Fig .(II): A:A photomicrograph of kidney of control rat show normal structure consisting of elements ofrenal cortex: renal corpuscle $(\mathbf{R})$, proximal convoluted tubule(P)and distal convoluted tubule(D).B:Thiamethoxam insecticide after 10 days showing atrophic glomeruli (A) and cloudy swelling in renal tubules(CS).C:Thiamethoxam insecticide after 20 days cloudy swelling in renal tubules (CS) with dilation of blood vessels (D) and few aggregation of inflammatory cells (IC). D:Thiamethoxam insecticide after 30 daysshowing increase cloudy swelling in renal tubules(CS), spreading atrophic glomeruli (A)and morecongestion of blood vessels with red blood cellsin the interstitial space between the tubules and glomeruli (C). E:Acetamiprid insecticide after 10days showing congestion in blood vessel with red blood cells(C), cloudy swelling in proximal and distal convoluted tubules(CS).F:Acetamiprid insecticide after 20days showing hemorrhage (H), atrophic glomeruli(A), cloudy swelling(CS) and aggregation of inflammatory cell (IC).G:Acetamiprid insecticide after 30days showing small aggregation of inflammatory cells(IC), congestion blood vessel (C), cloudy swelling(SC) in renal tubules and appearance area of fibrosis in renal tubules $(\mathbf{F})(\mathbf{H} \& \mathbf{E}, \mathbf{X} 200)$. 